\title{
番い関係の希薄なウグイスの一夫多妻について
}

\author{
濱 尾 章 二1 \\ 上越教育大学・生物学研究室
}

\section{Lack of Pair-bond: a Polygynous Mating System of the Japanese Bush Warbler Cettia diphone}

\section{Shoji HAMAO ${ }^{1}$}

Department of Biology, Joetsu University of Education, Yamayashiki-machi, Joetsu, Niigata 943

一夫一妻の婚姻形態が一般的な鳥類 (LACK 1968) の中で, 一夫多妻の種は特に注目して 研究されてきた（例えばアメリカでは，ハゴロモガラスAgelaius phoeniceus: ORIANS 1961, HOLM 1973; セジロミソサザイ Telmatodytes palustris: VERNER 1964, 1965). 日本であ，才 オョシキリ Acrocephalus arundinaceus (羽田・寺西 1968b, SAITOU 1976, EZAKI 1990, URANO 1990a, b) やセッカ Cisticola juncidis（母袋 1973, UEDA 1984, 1985, 1986）について, 詳細な研究がなされている.

ウグイス Cettia diphone は，さえずりが長期に及ぶことや体サイズに性的二型が見られ ることから, 一夫多妻の可能性が考えられている（山岸 1984, 上田 1987). しかし, やぶ の中を潜行するために（山階 1941, 清棲 1978）観察が困難であり, 繁殖期の生態について は主として巣の観察に基づいた繁殖諸活動の報告がなされているにすぎない（羽田・岡部 1970, GAO \& ZHANG 1985).

筆者は, ウグイスの婚姻形態, 番い関係の解明を目的として, 個体識別に基づく調查を 行った. 本論文では, 同一なわばりにおける複数雌の営巣, 営巣雌や他個体（雌雄）のな わばり内での存在状況を中心に繁殖生態について報告する. そして, ウグイスが番い関係 の希薄な一夫多妻の婚姻形態をむつ可能性について論議したい.

\section{調查 地}

調查は 1990 年と 1991 年に新潟県妙高高原町池の平地区 (北緯 $36^{\circ} 52^{\prime}$, 東経 $138^{\circ} 11^{\prime}$ ) で 行った.この地区は妙高山の東側山麓にあたり, 標高約 $700 \mathrm{~m}$ の傾斜の緩やかな土地であ る. 植生は主に, ミズナラ Quercus mongolica が主体の落葉混交林とスギ Cryptomeria japonica の植林からなる. また, ハンノキAlnus japonica を交えたヨシ Phragmites communis 湿原やヤマグワ Morus australis, コマユミEuonymus alatus f. ciliatodentatus などの低木林 （やぶ）あ見られる.なお，一般にウグイスが好むと言われているササ原（清棲 1959）は, 調查地では渓流沿いの傾斜地にわずかに見られるのみであった.

\footnotetext{
1 現所属：埼玉県浦和市立南高等学校. Present address: Urawa-minami High School, Tsuji 6-5-31, Urawa, Saitama 336.
} 
(a)

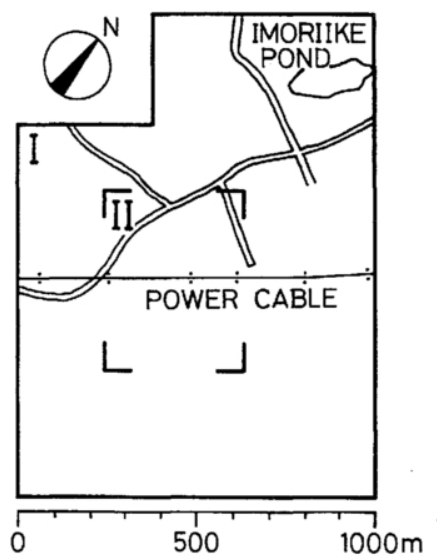

(b)

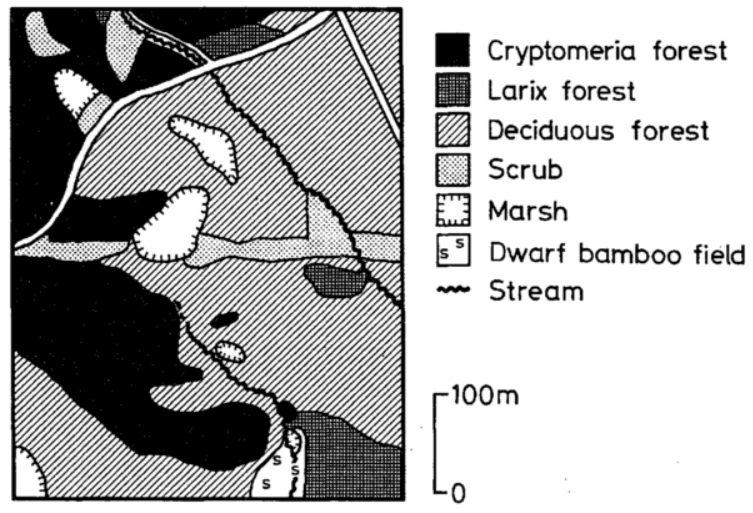

Fig. 1. (a) The study area. I: Census area, II: Intensive study area. (b) Vegetation map of the intensive study area.

調査にあたっては, センサス調査区とその中に含まれる精密調査区を設定した (Fig. 1). 前者は定期的になわばり雄の存在状況を確認するための 118 ha の区画, 後者は主として 1

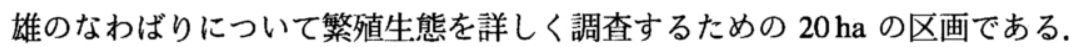

方法

\section{1) 個体識別}

調查にあたっては可能な限りの個体を捕獲し，標識を装着して個体識別した．捕獲には カスミ網を用い, 標識はセルロイド製の色脚環によった. 標識を装着した個体は 2 年間で 190 個体（成鳥 80 , 巣内雊 21 , 巣外雛 29 , 自立幼鳥 60) であった. 標識個体には通し番号 をつけ, この個体番号に雄ならば $\mathrm{M}$, 雌ならば F の記号を付して M38, F116のように表し た. 標識の確認, 行動の観察は主として双眼鏡 $(\times 8)$ によって行った.

2) 年齢及び性別の判定

その年生まれの幼鳥の多くは, 腹に黄色い幼羽があり, 成鳥と容易に区別できた. 幼羽 をもたない個体については, 安部 (1984) に基づいて, 頭骨の骨化が完了していない場合に 幼鳥と判断した.

成鳥については, 翼長によって雌雄を判定した. 黒田 (1933), 山階 (1941), 清棲 (1978), 小林 (1981) によると, いずれの場合も翼長 60-62 mm の個体はなく, それよりあ小さいむ のが倠, 大きいものが雄とされている. 安部 (1984) は秋季の標識調查における幼鳥を含む 141 個体の測定值から, 雌雄のサイズ分布には重複があり, 雌雄は判別できない場合があ るとしているが，翼長の分布を成鳥のみについて見ると $58 \sim 62 \mathrm{~mm}$ の個体を欠く 2 山型 をしている. 今回の調査における成鳥 80 個体の翼長分布は, $58 \sim 62 \mathrm{~mm}$ の個体を欠き, 2 つのグループに分離した (Fig. 2). また, 翼長の大きなグループの個体は小さなグループ の個体に比べて, 尾長, 跗蹠長, 体重が常に大きかった (Table 1). これらのことから, 翼 


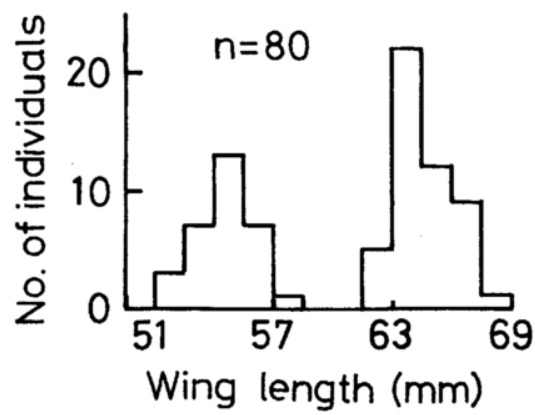

Fig. 2. Frequency distribution of wing length of adult Japanese Bush Warblers. Data pooled, 1991 and 1991.

Table 1. Comparison of morphological measurements between two groups of adult Japanese Bush Warblers. Adults are divided into two groups based on the frequency distribution of wing length. 'Group A' includes small individuals and 'Group B' includes large individuals (see Fig. 2). Data pooled, 1990 and 1991.

\begin{tabular}{lccrcc}
\hline \hline & \multicolumn{2}{c}{ Group A $(n=31)$} & & \multicolumn{2}{c}{ Group B $(n=49)$} \\
\cline { 2 - 3 } \cline { 5 - 6 } & $\bar{x}$ & range & & $\bar{x}$ & range \\
\hline Wing length (mm) & 54.4 & $51.3-57.0$ & & 64.6 & $62.2-67.7$ \\
Tail length (mm) & 57.0 & $53.4-60.7$ & & 68.1 & $64.8-73.1$ \\
Tarsus (mm) & 22.3 & $21.4-23.2$ & & 25.6 & $24.5-27.1$ \\
Culmen (mm) & 10.9 & $9.9-11.7$ & & 12.1 & $10.6-13.8$ \\
Body weight (g) & 11.5 & $10.0-13.7$ & & 19.6 & $14.8-22.3$ \\
\hline
\end{tabular}

長の大きなグループ（49 個体）を雄，小さなグループ（31 個体）を雌と判断した．なお， 抱卵斑の発達が認められた 18 個体はすべて小さなグループに, 排泄孔部の円筒状の突起 が認められた 17 個体はすべて大きなグループに属していた.

3) センサス調査区における調査

センサス調査区では, なわばり雄の個体識別, 存在の有無の確認を行った. ただし, 1990 年は調查が不定期（5８月に 5 回）であり，一部の個体に標識をつけるにとどまった.

1991 年は 4 月中旬から 8 月中旬までの間, 半月に 1 回全域を踏查し, さえずっている雄 の所在を確認した. 調查は 05:00-12:00 の間に, 調査区内に 100〜 200m 間隔で設定した ルートを時速約 $2 \mathrm{~km}$ で歩いて行った. ウグイスのさえずりは特徴的で遠くまでよく聞こ えるので, 雄の発見は容易であった. さえずっている雄がいない場所では, 他所で録音し た雄のさえずりを再生して雄の誘引を試み, 発見むれのないようにした.

発見した雄については標識の確認に努め, 未標識の場合は速やかに捕獲するようにし た. やむを得ず捕獲ができなかった場合には，さえずりの特徴をメモしておき，これに よって個体を識別した. 百瀬 (1986) あ述べているように, さえずりのレパートリーから個 体を識別することは十分可能であった，さえずりによって個体識別した雄には 1000 を越 える個体番号を与えたが, このような個体は 2 年間で 7 個体であった.

4) 精密調査区における調査

精密調查区では, 雄のマッピング, 繁殖経過の記録など繁殖生態にかかわる詳細な調查 
を行った.

1990 年は 4 月中旬から 8 月中旬にかけて, 調查区に確立された 4 なわばりについて, 合 計 132.7 時間の雄の追跡観察と 29.9 時間の巣の観察を行った. しかし, 巣の探索が不徹底 であったため, 巣や営巣雌の存在の有無を正確に把握できなかった.

1991 年は調查区の中に含まれる 1 雄 (M98) のなわばりのみについて, 集中的に調查を 行った. 調查期間は M98 が渡来してから消失するまでの 1991 年 4 月 16 日-6月 30 日で あった.

i) 侵入雄や雌を発見するために, 連日あるいは 2 日間に 1 回 5-7 時間，カスミ網を

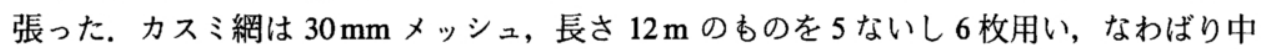
心部分の低木林内の小道や湿原の縁の決まった場所に張った. ただし, 雄のなわばりの形 が変化したり, 網場の近くに巣が発見された場合には, 一部の網を移動したことああった. 捕獲によるなわばり雄の消失や雌の巣の放棄は見られなかった.

ii）定期的に徹底した巣の探索を行った．個体の観察から巣の有無あるいは場所を推定 することができなかったため，3 日間に 1 回の割合でなわばり内をくまなく歩いて巣の発 見に努めた.

iii) 発見した巣の状況は, 可能な限り毎日記録した. 造巣, 抱卵, 育雊の観察はやぶの 中にブラインドを設置して行った他, ビデオ・カメラを用いて記録した.

iv) 定期的になわばり雄のマッピングを行った. マッピングは 2-4 日間に 1 回，日の出 から 10:00 までの間に連続して 4 時間行い, タイム・マッピング法（中村 1969）によって 1 分間隔で位置（活動点）を記録した. 同時に 1 分間ごとにさえずった場合は 1 ，さえずら なかった場合は 0 のスコアを記録した. さえずり頻度はこれを 4 時間 (240 分間)について 合計し，0-240のスコアで表した. また，さえずりを記録した活動点をすべて含む凸多角形 を描き, ソング・エリアとした. ソング・エリアの面積を求める際にはパーソナル・コン ピュータを用い, BASIC 上で走る自作のプログラムによって, 多角形の頂点の座標から算 出した.

\section{結果}

\section{1) なわばり}

調査地では, 雄のさえずりは 4 月中旬から 8 月中旬まで続いた．雄のさえずる範囲は, 互いに重複することはなく明瞭に分離していた．雄間の争いは 2 年間に 2 例観察された が, いずれの場合もソング・エリアの所有者が侵入個体を追い払った.これらのことから, さえずりによって占有されているンング・エリアをなわばりと判断した.

1991 年には, センサス調査区では, 計 35 個体の雄がのべ 43 のなわばりをむった. しか し, 36 (83.7\%) のなわばりは 2 力月以下の短期間しか維持されず (Fig. 3), 1 度の調查で 確認されるなわばり雄の数は 10-14 ( $\bar{x}=11.7, n=9)$ であった. なわばりをあたない放浪状 態の雄む多く確認された. これらの個体は一切さえずりや地鳴きをせず, 捕獲によっての み発見された．定期的にカスミ網を張った M98 のなわばりでは, 16 雄の侵入が確認され た (Fig. 4). これらの雄のうち 13 個体（なわばり所有の状態で再度侵入した 1 個体を含 む）は，なわばりをむっていない放浪状態のあのであった. また，この 13 個体のうち 6 個 


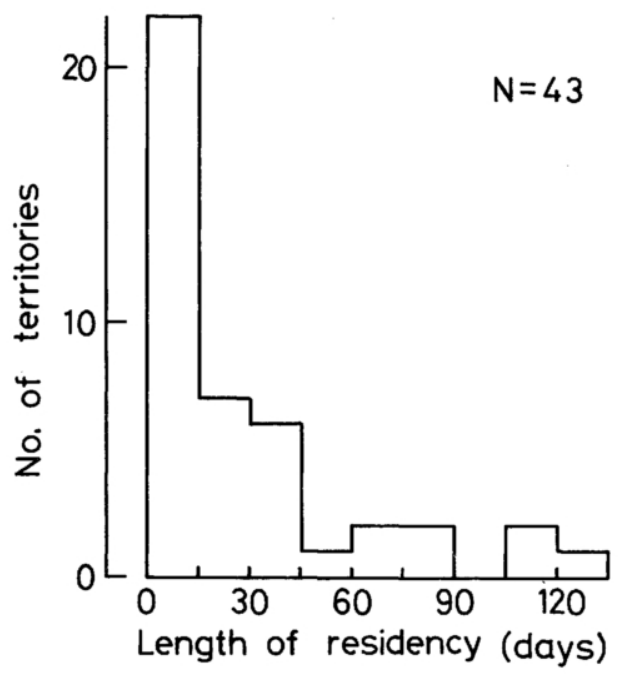

Fig. 3. Frequency distribution of length of residency of male Japanese Bush Warblers in 43 territories established in 1991.

\begin{tabular}{|c|c|c|c|}
\hline MALE & APR. & MAY & JUNE \\
\hline M 97 & $\bullet$ & \multirow{16}{*}{$\infty$} & \\
\hline M 99 & $\bullet$ & & \\
\hline M 102 & $\bullet$ & & \\
\hline M103 & の & & \\
\hline M105 & • & & \\
\hline M 112 & & & \\
\hline M 121 & & & \\
\hline M 9 & & & \\
\hline M123 & & & \\
\hline M126 & & & \\
\hline M 32 & & & \\
\hline M129 & & & \\
\hline M 140 & & & • \\
\hline M131 & & & • \\
\hline M142 & & & $\bullet$ \\
\hline M107 & & & c \\
\hline
\end{tabular}

Fig. 4. Intrusion by male Japanese Bush Warblers into M98's territory in 1991. 


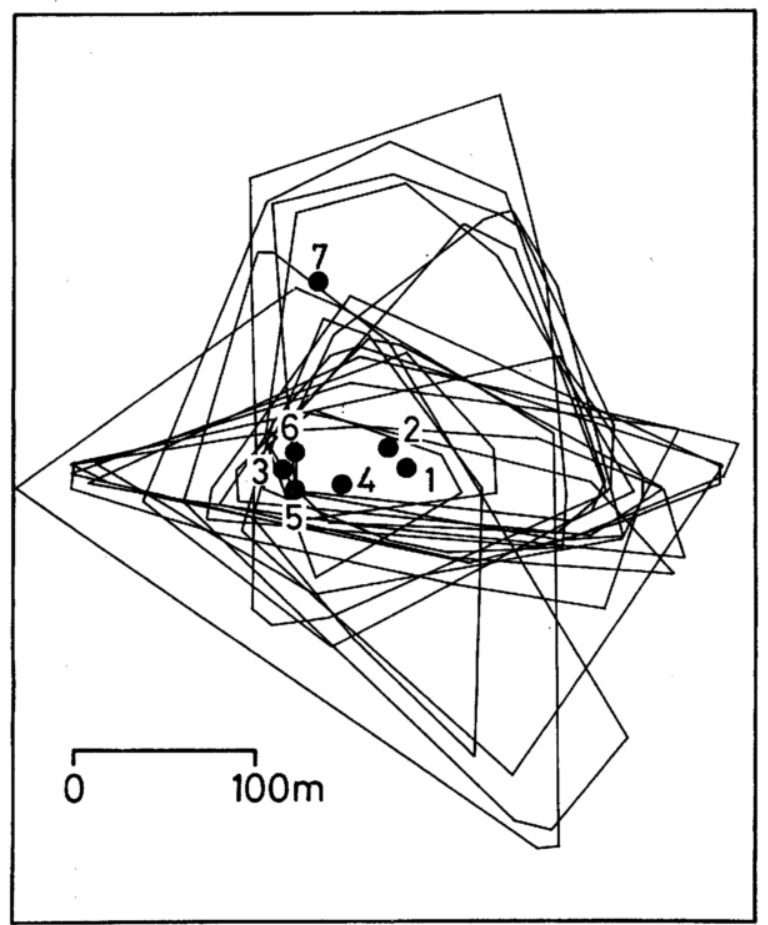

Fig. 5. Location of nests of Japanese Bush Warblers in M98's territory in 1991. The polygons indicate daily activity ranges of M98 from 23 April to 30 June. The frame shows the intensive study area.

体は，侵入の前または後になわばりをむったことが確認されており，放浪状態となわばり 所有の状態とは互いに変化しやすいことが示唆された.

2) 同一なわばりにおける複数雌の営巣

定期的に巣の探索を繰り返した M98 のなわばりでは，7巣が発見された (Fig. 5). 巣の 分布は, M98 が常にさえずりによって占有していた低木林やヨシ湿原に集中していた. 各 巣は 5 月中旬から 6 月下旬にかけて時期を重ねて営まれており, 巣 1 と巣 2 では産卵期む 一致していた (Fig. 6). 営巣雌はそれぞれの巣で異なっていたが，巣 4 のみは後に巣 6 を 構えた F124 が営巣した可能性がある.

M98 以外の雄のなわばりでは，発見できなかった巣むあったと思われるが，1990年に M1 と M1001 のなわばり内でそれぞれ少なくとも 2 巣が営まれていた. これらの場合で あ, 2 巣は時期を重ねて営まれており, 営巣雌はそれぞれ別の個体であった．したがって, ウグイスでは, 複数の雌が同一雄のなわばり内で同時に営巣することは例外的なことでは なく，ある程度の頻度で起きているものと考えられる.

3) 繁殖生態及び子の世話

巣はやぶの中の低い場所につくられることが多かった. 2 年間の観察によると，巣はイ ヌッゲ Ilex crenata やエゾイボタ Ligustrum Tschonoskii f. glabrescens の他, ノイバラRosa multiflora やクマヤナギ Berchemia racemosa のほふくした枝などにつくられ，巣の入口ま 


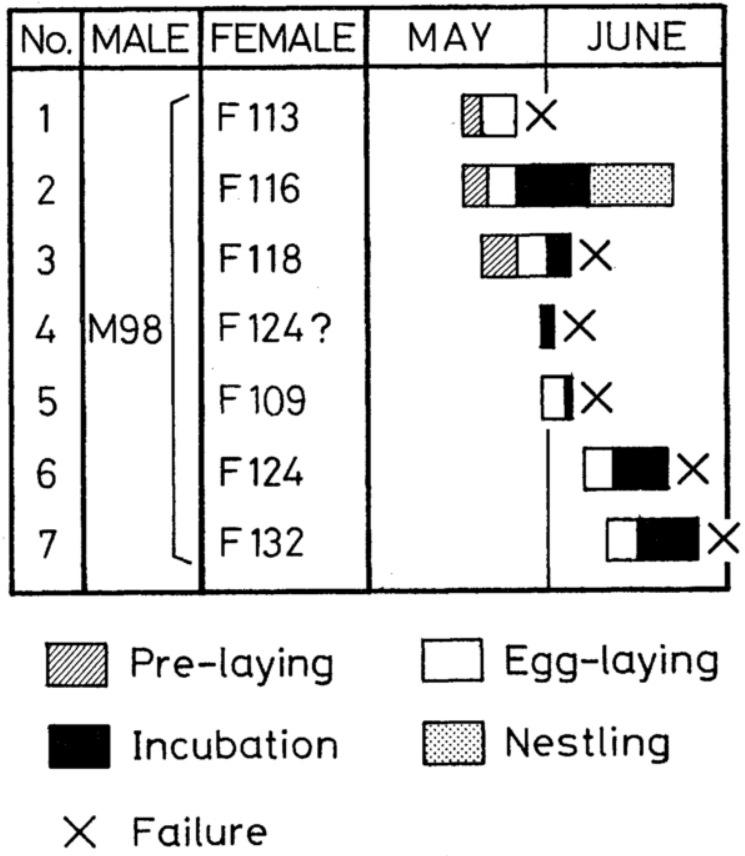

Fig. 6. Breeding chronology of female Japanese Bush Warblers which nested in M98's territory in 1991.

Table 2. Role of female Japanese Bush Warbles in nest building and in caring for young. Data pooled, 1990 and 1991.

\begin{tabular}{lccc}
\hline \hline \multicolumn{1}{c}{ Activity } & $\begin{array}{c}\text { No. nests } \\
\text { observed }\end{array}$ & $\begin{array}{c}\text { Total observation } \\
\text { time }(\mathrm{h})\end{array}$ & $\begin{array}{c}\text { Frequency of the } \\
\text { activity }(/ \mathrm{h})\end{array}$ \\
\hline Carrying nest materials & 3 & 10.0 & 3.8 times \\
Incubation & 4 & 62.8 & $43.1 \mathrm{~min}$ \\
Brooding of nestlings ${ }^{1)}$ & 3 & 35.5 & $20.0 \mathrm{~min}$ \\
Feeding nestlings & 8 & 81.7 & 5.5 times \\
\hline
\end{tabular}

1) Data for nests with nestlings aged 0-4 days-old are shown.

での高さは平均 $0.54 \mathrm{~m}(0.05-1.40 \mathrm{~m} . n=28$. 使用後に発見した巣を含む) であった．

巣の観察は, 2 年間で 7 なわばりの 10 巣について 154.5 時間行った. 訪巣個体はどの繁 殖ステージにおいてあ, それぞれの巣ごとに特定の 1 個体の雌に限られていた. 造巣, 抱 卵，育雊はすべてその雌のみによって行われた (Table 2). 造巣は 3 巣について，それぞれ 初卵産下の 4 日前，5 日前，13 日前から観察したが，完成すると側方に入口をむった球形 になる巣がまだ皿状の時点から，雌のみによってっくられていた． どの繁殖ステージにお いても雄の訪巣は見られなかったが，抱卵期に雄が偶然巣に近づいたと思われる様子が 1 例ビデオに記録された。.すなわち，1991年6月3日（10:48), 谷渡り鳴きをしていた雄 (M98) がだんだんと近づいて来て, 抱卵 11 日目の巣（巣 2, Fig. 5) の約 $40 \mathrm{~cm}$ 前の枝にと まったところ, 直ちに抱卵中の雌 (F116) が巣から飛び出して雄に突きかかって行き, こ 
れを追い払った. 雌は 3 分後に，㷌巣し抱卵を続けた。

巣にシマヘビ Elaphe quadrivirgata やアオダイショウ E. climacophora が近づいた例は 2 年間で 3 回観察したが，その際のモビングは雌のみが行った. 2 年間で 13 の巣立ち雊の群 れを観察したが, これらの雛に対する給餌, 観察者を発見しての警戒あ雌のみが行ってい た. 2 年間で 273.7 時間行った雄のマッピングにおいても, 雄による造巣や子の世話は一切 観察されなかった.

繁殖の失敗は多く, 2 年間で産卵期までに発見した 11 巣のうち巣立ちに至ったのは 3 巣 (27.3\%) であった. 繁殖が失敗したケースでは, シマへビによる雛の捕食が 1 例ビデオで 記録された他，すべての卵や雛が一度に消失していて捕食を受けたと考えられる場合が多 かった. 雛の餓死は見られなかった. 調查地ではシマヘビ, アオダイショウの他, マムシ Agkistrodon blomhoffi, ヤマカガシ Rhabdophis tigrinus, ジムグリ Elaphe conspicillata, また夕 ヌキ Nyctereutes procyonoides やキッネVulpes vulpes が観察されており，やぶの中の低い場 所に営巣するウグイスでは, 捕食による繁殖失敗が多いむのと思われた.

4) 雄のなわばりと雌の存在様式

雌は繁殖を失敗した後の再営巣や雊を巣立たせた後の第 2 繁殖の際に, 雄のなわばりを 変える傾向があった. 2 年間で繁殖の失敗 10 例, 巣立ち 7 例を観察したが, 同じなわばり 内で再び営巣した例は確認されなかった. 1990 年 6 月 8 日に M 1 のなわばりで雛を巣立た せた F5 は，このなわばりから消失したが，9月 21 日に隣接するなわばりで別の雊を連れ ているのが観察された。このように, 巣外育雛と雌の観察から第 2 繁殖の際に雄のなわば りを変えたと推定される例は, 他にも 2 年間で 2 例見られた.

定期的にカスミ網を張った M98 のなわばりでは, 21 個体の雌が確認された (Fig. 7). こ のうち 6 個体はこのなわばり内で営巣したことが確認されており, 他の 15 個体のうち 3 個体については, 前後に近隣のなわばりで営巣したことが確認された.

なわばり内の営巣雌間の関係は, 親和的なものであった. Fig. 8 は M98 のなわばりに 3 巣が同時に存在した 15 日間に, 各営巣雌を確認した地点を示したものである. 各雌の行動 範囲は明らかに重なっている. 営巣雌同士が出会った例は 2 年間で 3 回観察したが, いず れの場合でも争いはなく，互いに無視するように行動していた．また，なわばり雄に比べ ると雌はかなり狭い範囲で行動する傾向が見られた (Fig. 8). 営巣雌を巣のあるなわばり の外で観察した例は，2 年間を通じてなかった。

5) なわばり雄と営巣雌の関係

なわばり雄と営巣雌との間の交尾は，観察できなかった．交尾は 2 年間に 2 例観察した が, いずれの場合も雌の標識を確認できなかった．これらの例では, 求愛は独特のさえず りによって始まった. 求愛のさえずりは, 通常のさえずりと同じパターンだが著しく音圧 の低い小声のさえずりである（百瀬 1989）．雄はこのさえずりをしながら翼を半ば開いて 小刻みに震わせる雊の䭒乞いに似た行動（幼形行動）をとり, 同様な幼形行動をとる雌に 接近して交尾を行った. また, 交尾の確認はできなかったものの, なわばり雄が営巣雌に 対して同様な行動をとるのが, 2 年間で 3 例観察された。 しかも, そのうち 2 例では, 雌も 幼形行動を行っていた. なお, これらの求愛が見られたのは, それぞれ初卵産下の 3 日前, 4 日前，6日前であった.

求愛の他には, なわばり雄と営巣雌の間に番いの関係を感じさせる行動を見い出すこと 


\begin{tabular}{|c|c|c|c|c|}
\hline FEMALE & BREEDING & APR. & MAY & JUNE \\
\hline $\begin{array}{l}F 106 \\
F 109 \\
F 110 \\
F 111 \\
F 145 \\
F 113 \\
F 114 \\
F 115 \\
F 116 \\
F 117 \\
F 118 \\
F 119 \\
F 120 \\
F 124 \\
F 125 \\
F \quad 50 \\
F 132 \\
F 133 \\
F 141 \\
F 144 \\
F 130\end{array}$ & $\begin{array}{l}+ \\
+ \\
+ \\
+ \\
+\end{array}$ & $\bullet$ & 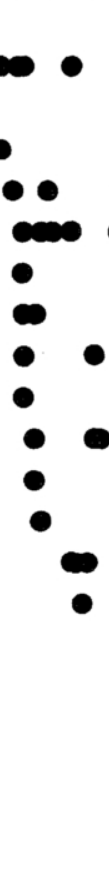 & $\bullet$ \\
\hline
\end{tabular}

Fig. 7 Appearance of female Japanese Bush Warblers in M98's territory in 1991.

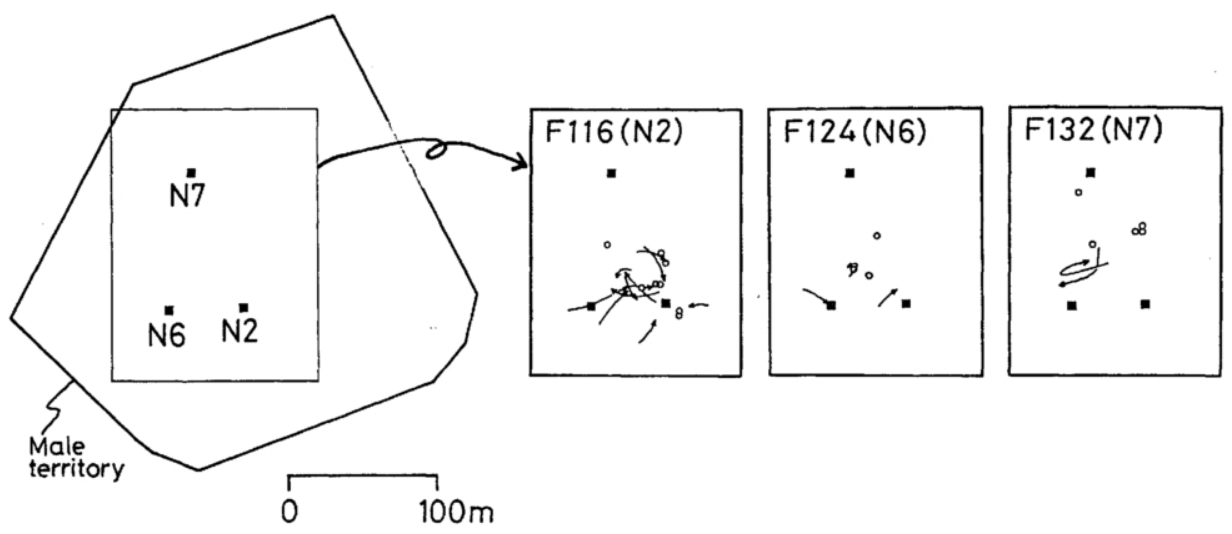

Fig. 8. Distribution of activity points of three nesting female Japanese Bush Warblers within M98's territory during 6-20 June, 1991. Arrows indicate direction of movements.

はできなかった，前述のように，造巣，抱卵，育雊は雌のみによって行われ，雄は関与し なかった. 雌に対する雄の追尾行動や巣場所を提示する行動, 営巣を促すような行動も, 2 年間を通じてまったく観察されなかった，また，M98 のさえずり活動の時期的変化を見 


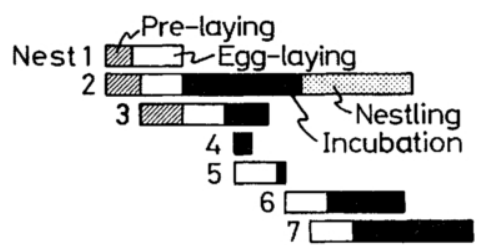

(a) Frequency of singing

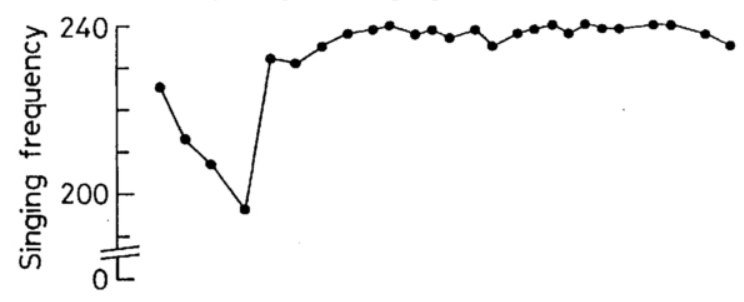

(b) Area of territory

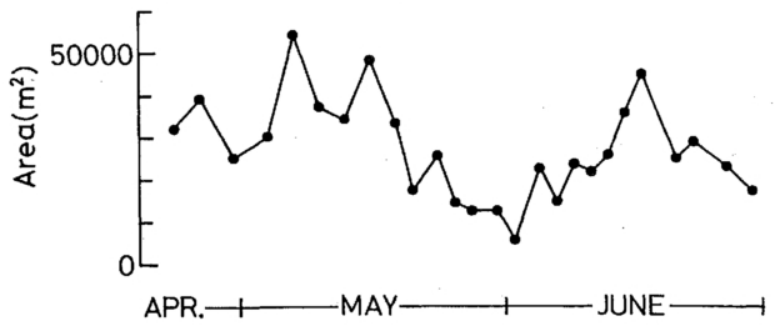

Fig. 9. Seasonal changes in frequency of singing and area of territory of M98 in relation to the breeding chronology of female Japanese Bush Warblers in the territory in 1991. Singing frequency during a 240-min observation-unit was scored from 0 to 240 by checking whether the male sang or not every 1-min.

ても, 渡来後の一時期を除いて高いさえずり頻度が維持されており, 営巣雌のステージと 関連した変化は見られなかった (Fig. 9a). 一方, M98 のなわばりの面積は営巣雌が多くい ると小さくなる傾向があり (Fig. 9b), なわばり内の巣の数となわばり面積の間には有意な 負の相関が見られた (SPEARMAN の順位相関係数, $r_{s}=-0.59 . P<0.01 . n=26$. 両側検定).

\section{考察}

今回の調查では, 3つのなわばりにおいて, 複数雌による営巣が確認された. 特に, 精密 な調查を行った 1 なわばりでは, 2 力月の間に 6 ないし 7 雌によって 7 巣が営まれていた. これらのことは, ウグイスが一夫多妻の婚姻形態をむつ可能性の高いことを示している.

婚姻形態を考える上で重要となるのは, 雄・雌の性関係である. ウグイスの交尾は求愛 の状況から推定してやぶの中で行われることが多いらしく，標識雌の交尾は観察できな かった. しかし, 筆者は以下の 2 点から, なわばり雄と営巣雌の間には性関係のある場合 が多いと考える. その一点目は, なわばり雄が営巣雌に求愛を行っていることである. 雌 雄両者の標識が確認できた 3 例の求愛の観察では, 雄が求愛さえずりをしながら求愛の幼 
形行動をとっており，そのうち 2 例では雌あ幼形行動を行っていた．また，3例のいずれも が初卵産下の 3-6.日前に観察された。これらのことは, 営巣雌の卵の受精がなわばり雄に よって行われる場合のあることを強く示唆している. 第二には, 雌は受精可能な期間, 雄 のなわばりの外で行動することが少ないと考えられることである. 雌の行動圏をステージ に分けて検討するだけのデー夕はないが, 営巣雌の行動する範囲は雄のなわばりに比べる とかなり狭く (Fig. 8), 営巣雌をなわばりの外で発見した例はまったくなかった. また, 造 单は雌のみによって行われ，少なく見積っても5 日間を要した. これらのことから判断す ると, 雌は受精可能期間と推測される初卵産下数日前から産卵期にかけて, 巣のあるなわ ばりの中にいることが多く, 卵の受精はそのなわばりの雄によって行われる場合が多いと 考えられる.

侵入雄による交尾の可能性は低いと考えられる. 他の雄のなわばりに侵入する雄は多く 確認されたが，それらはいずれす，求愛さえずりを含めてまったく鳴くことがなかった. ウグイスの交尾は, 前述したような観察結果によれば, 求愛さえずりからの一連の求愛行 動によって可能になるあのと思われる.このため，侵入雄による交尾は起こりにくいと考 えられる.

以上のように, ウグイスではなわばり内に複数の巣が営まれることがあり, なわばり雄 と営巣雌は性関係をあつ場合が多いと推定されることから，1雄が多雌と性関係をむつ一 夫多妻の婚姻関係をあつすのと考えられる.

一夫多妻をむたらす生態的要因として, EMLEN \& ORING (1977) は繁殖に必要な資源の 分散状態を考えた. 上田 (1986) はセッカにおいて, 慨の得やすさの重要性を指摘してい る. 筆者は, ウグイスの一夫多妻をあたらす生態的要因の一つとして，高い捕食圧が重要 であると考える. ウグイスでは繁殖の失敗が多く，再営巣が頻繁に起こっていると考えら れた. 繁殖期が長いために, 雊を巣立たせた後の第 2 繁殖もかなり行われていると思われ る. そして, このような再繁殖の際, 雌は雄のなわばりを変える傾向があった. 造巣から 育雊まで雌が単独で行えること, 雌間の関係が親和的であることから, 雄のなわばりにと らわれずに再繁殖の場を選択できるのであろう. 雌が雄のなわばりを変えて再繁殖を繰り 返すことは, 時間的に重複しない一妻多夫の関係をむつことになる.このことを雄の立場 から見ると, 多くの雌がなわばりを訪れ (Fig. 7), どの時期でも配偶可能な雌が得やすい ということになる. ウグイスの一夫多妻は, 高い捕食圧に起因する頻繁な雌の再営巣に よって生じている可能性が高いと考えられる.

ウグイスの雄は一切子の世話を行わなかった. また, 直接的な子の世話以外にも雌や子 に対する寄与・貢献が見い出されなかった．このことは一夫多妻の種の中で，ウグイスに 特徴的なことである. 例えば，オオヨシキリ（羽田・寺西 1968a, b, URANO 1990a）やイエ ミソサザイ Troglodytes aedon (KENDEIGH 1941) では, 雄も雌とともに雊の世話をする．ま た， セジロミソサザイ (VERNER 1964, 1965) では個体群によって, ヨーロッパウグイス Cettia cetti (BIBBY 1982) やミソサザイ T. troglodytes (KLUIJVER et al. 1940) では個体によっ て差があるが，雄による子の世話が見られる. ウグイスでは，今回 7 なわばりの 10 巣を 154.5 時間調查したにあかかわらず, 雄による世話はまったく見られなかった. 羽田・岡部 (1970), GAO \& ZHANG (1985) によっても，本種の子の世話は雌のみによって行われると 報告されている．上田（私信）によると，小笠原のウグイスは雄も雊に給餌すると言うが, 
この場合繁殖生態, 婚姻形態が他の地域とは大きく異なっているらしい, 一般には, ウグ イスでは雌のみが造巣, 抱卵, 育雊を行い, 雄が子育てに関与しないと言えるであろう.

子の世話以外の点についても, 求愛以外に雌雄の接点を見い出すことはできなかった. オオョシキリの雄は番い形成の時期にさえずりが不活発になり (EZAKI 1987, URANO 1990 b), 雌に対して追尾行動や求愛給䬣を行う（羽田・寺西 1968a）. セッカ（母袋 1973, UEDA 1984）やミソサザイ（羽田・小堺 1971）の雄は, 次々と求愛巣をつくっては雌を招き多妻 となる. ウグイスでは, 外巣の構築から雌が単独で行っていた. また, 雄のさえずりも常 に活発で雌の獲得や繁殖ステージと対応した变化は見られなかった (Fig. 9a). 273.7 時間 の雄の追跡によっても, 雌に巣場所を提示する行動や雌に対する追尾行動などは観察され なかった. ウグイスの雄は, 雌との交尾だけを指向しているように思われる.

見在知られている中で, 最あウグイスに似た婚姻形態をもつものはセッカであろう. セッ力の雄は求愛巣をつくり雌を招いて交尾をした後は, 一切抱卵や育雊を手伝わず（母 袋 1973, UEDA 1984), 巣に近寄ることあない（上田 1986). 雄は捕食者やヒトが巣に近づ くと警戒声を発して飛び回るが, 他には交尾以後, 雌や子との接点は見い出せないと言う (母袋 私信). このような希薄な番い関係は, ウグイスのものとよく似ている. また, さ えずりが長期に及ぶこと, なわばり雄の頻繁な交代, 放浪雄の存在, 再繁殖の際に雌が雄 のなわばりにとらわれずに移動すること (UEDA 1986) を含めて, 両種はよく似た社会シス テムをあっていると考えられる. しかし, セッカでは雄が求愛巣をつくるという点が, ウ グイスとは大きく異なる. ウグイスの雄では, 交尾以外に繁殖に関する寄与, 貢献はまっ たく見い出すことができない.

巣が集中的に分布する部分はいつも雄が防衛していた場所であったこと (Fig. 5) や，な わばり内に多くの巣ができると雄のなわばりが縮小する傾向があったこと (Fig. 9b) は, なわばり雄が巣場所の決定に関与したり, 営巣雌との間に番いとしての何らかの関係を あって行動していることを示すすのと判断することす可能である. しかし, 巣が集中する 部分は低木林や湿原の部分であり営巣場所が限定されていたと考えられること, 巣ができ た後で雄の活動がその周囲に集中する傾向があったことから, 雄の行動によって巣場所が 決定されているとは考えられない. 雄は営巣雌かそれ以外の雌かによらず，ただ単になわ ばりの中にいる雌に誘引され接近して行くように思われる. 雌が繁殖期に特有なチーチー という地鳴きをした際に, 雄が谷渡りと言われる長く続く鳴き声を発したり, 雌の方へ飛 んで行きソング・ポストを移動させることもあったが, 雌に連れ添ったり給餉をするなど の番いの関係を考えさせる行動は見られず，やはり雄は営巣雌かどうかによらず雌を発見 して接近を試みているあのと考えられる. しかし, これらの観察事実については, 今後さ らに調査, 検討が必要であろう.

いずれにしても, ウグイスの番い関係は, 今までに知られているなわばりをはるタイプ の一夫多妻の中では, きわめて希薄なものであると考えられる.

\section{謝辞}

この研究に対して終始暖かい激励と助言を頂いた上越教育大学の中村登流教授に厚く御礼申し上げ る. また, 上越教育大学の中村雅彦氏, 長野県坂城町立坂城小学校の母袋卓也氏には種々の助言を頂 くとともにビデオ機材の貸与をお願いし, 立教大学の上田恵介助教授には文献の入手と英文の校閲に 
便宜をはかって頂いた，さらに，長野県茅野市立米沢小学校の下山良平氏と本誌レフェリーの有益な 助言, および Carola Haas 氏の英文校閲によって本稿を完成することができた．これらの方々にも， 樑く感謝したい.

\section{摘 要}

1) 1990,91 年の繁殖期に新潟県妙高高原において, 190 個体（うち成鳥 80 個体）のウグイスを個 体識別して, 婚姻形態の解明を目的とした調查を行った.

2) 1991 年, $118 \mathrm{ha}$ のセンサス調查区では, 踏查の際 10-14 個体 $(\bar{x}=11.7, n=9)$ のなわばり雄が 確認された. 同調查区ではシーズン全体で 35 個体のなわばり雄が確認された. なわばり雄の交代は頻 繁に起こっており,なわばりは短期間しか維持されなかった.

3）他のなわばりにさえずることなく侵入する雄が見られた. 詳細に調查した 1 なわばりでは, 20 例の侵入が確認され, このうち 15 例が放浪雄によるものであった.

4) 雄のなわばり内で同時期に複数の巣が発見されることがあり, 精密に調查した 1 なわばりで は, 1 シーズンに 6 ないし 7 雌によって 7 巣が営まれた.

5) 造巣, 抱卵, 育雊はすべて雌のみによって行われ, 捕食者に対するモビング, 巣外育雊を含め, 雄は一切の子の世話を行わなかった.

6) 捕食によるものと推定される繁殖失敗が多かった. 第 2 繁殖を含めて, 雌は再繁殖の際に雄の なわばりを変える傾向があった.

7) 詳細に調査した 1 なわばりでは 21 個体の雌が確認され, 雄にとってどの時期であ配偶可能な 雌が供給されやすい環境であることが示された.

8) 営巣雌の行動範囲は雄のなわばりに比べてかなり狭く, 結果的に雌がなわばり外で行動する ことは少ないあのと考えられた．また, 同一なわばりに営巣した雌間の行動圈は重複しており, 排他 的な行動は見られなかった.

9) なわばり雄と営巣雌間には, 求愛以外に接点が観察されなかった. 雄のさえずり頻度にも営巣 雌のステージと対応した変化は見られず, 雌に対する雄の追尾行動す観察されなかった.

10) これらのことから, ウグイスは番い関係がきわめて希薄な一夫多妻の婚姻形態をもつものと 考えられた.

\section{SUMMARY}

1) Mating system of individually marked Japanese Bush Warblers Cettia diphone was studied at Myokokogen $\left(36^{\circ} 52^{\prime} \mathrm{N}, 138^{\circ} 11^{\prime} \mathrm{E}\right.$, alt. $\left.700 \mathrm{~m}\right)$, central Japan, during the $1990-91$ breeding seasons.

2) Territories were maintained for short periods. Although 35 territorial males were confirmed within a census area in a breeding season, only 10-14 $(\bar{x}=11.7, n=9)$ of them were observed on each survey.

3) Intrusions into territories by non-residential males were observed frequently. These intruders never sang there. In M98's territory, 15 intrusions by floating males and five intrusions by territorial males were observed.

4) In three territories, multiple females were observed breeding. In M98's territory, seven breeding attempts were made by 6 or 7 females within a season.

5) Females built nests and took the full share of parental care, including incubation, feeding nestlings, rearing fledglings, and mobbing predators.

6) Breeding failures, which might have been caused by predation, were observed frequently. There was a trend for females to leave a territory after one breeding attempt.

7) At least 21 females appeared in M98's territory, which suggests the presence of many potential mates for the male. 
8) Home ranges of breeding females were much smaller than male territories. Female ranges seemed to be restricted to within male territories. The ranges of females nesting in the same territories overlapped. Agonistic behavior between them was not observed.

9) Singing activity of males was vigorous throughout the breeding season irrespective of the nesting stages of breeding females. No contacts between males and nesting females, including escorting behavior of females by males, were observed.

10) These results strongly suggested that the mating system of the Japanese Bush Warbler was advanced polygyny characterized by lack of pair-bonds.

\section{引 用 文 献}

安部直哉, 1984. 標識調查におけるウグイスの雌雄判別基準としての翼長. 山階鳥研報 16: 151-158. BIBBY, C. J., 1982. Polygyny and breeding ecology of the Cetti's Warbler Cettia cetti. Ibis 124: 288-301. EMLEN, S. T. \& ORING, L. W. 1977. Ecology, sexual selection, and the evolution of mating systems. Science 197: 215-223.

EZAKI, Y., 1987. Male time budgets and recovery of singing rate after pairing in polygamous Great Reed Warblers. Jap. J. Ornithol. 36: 1-11.

1990. Female choice and the causes and adaptiveness of polygyny in Great Reed Warblers. $J$. Anim. Ecol. 59: 103-119.

GAO, W. \& ZHANG, K. 1985. On the breeding behaviour of the Singing Bush Warbler. Acta Zool. Sinica 31: $162-169$.

羽田健三・小堺則夫, 1971. ミソサザイの一夫多妻制について．信大志賀業績 (10): 35-47.

羽田健三・岡部剛士， 1970. ウグイスの生活史に関する研究 1. 繁殖生活. 山階鳥研報 6: 131-140.

羽田健三・寺西けさい，1968a，オオョシキリの生活史に関する研究 I. 繁殖生活. 日生態会誌 18: 100-109.

— 1968b. オオヨシキリの生活史に関する研究 II. Polygyny and territory. 日生態会誌 18: 204-212.

Holm, C. H., 1973. Breeding sex ratios, territoriality, and reproductive success in the Red-winged Blackbird (Agelaius phoeniceus). Ecology 54: 356-365.

Kendeigh, S. C., 1941. Territorial and mating behavior of the House Wren. Illinois Biol. Monogr. (18): 1-120.

清棲幸保，1959．原色日本野鳥生態図鑑 I，大阪，保育社。

1978. 増補改訂版日本鳥類大図鑑 I，東京，講談社。

Kluijver, H. N., Ligtvoet. J., VAn Den Ouwelant, C. \& ZegwaARd, F. 1940. De levenswijze van den Winterkoning, Troglodytes tr. troglodytes (L.). Limosa 13: 1-51.

小林桂助, 1981. 原色日本鳥類図鑑. 大阪, 保育社.

黒田長禮, 1933. 鳥類原色大図説. 第 1 巻. 東京, 東京修教社書院.

LACK, D., 1968. Ecological adaptations for breeding in birds. Methuen, London.

百瀬 浩, 1986. 音声コミュニケーションによるなわばりの維持機構. 山岸哲 (編), 鳥類の繁殖戦略 (下)：127-157. 東京, 東海大学出版会.

1989. ウグイスの音声コミュニケーションに関する研究. 京都大学学位論文.

母袋卓也, 1973. セッカの雄の行動と一夫多妻制. 山階鳥研報 7: 87-103.

中村登流，1969。エエナガの個体群の行動圈構造 I. 冬期群の行動圈と群れテリトリイ．山階鳥研報 $\mathbf{5}$ : 433-461.

Orians, G. H., 1961. The ecology of Blackbird (Agelaius) social systems. Ecol. Monogr. 31: 285-312.

SAIToU, T., 1976. Breeding biology of the Eastern Great Reed Warbler, Acrocephalus arundinaceus orientalis. Misc. Rep. Yamashina Inst. Ornithol. 8: 135-156.

UEDA, K., 1984. Successive nest building and polygyny of Fan-tailed Warblers Cisticola juncidis. Ibis 126: 221-229.

1985. Juvenile female breeding of the Fan-tailed Warbler Cisticola juncidis: occurrence of two generations in the year. Ibis 127: 111-116. 55.

上田恵介, 1986. セッカの発達した一夫多妻制社会. 山岸哲 (編), 鳥類の繁殖戦略 (上)：78-106. 東 
京, 東海大学出版会.

- 1987. 一夫一妻の神話. 鳥の結婚社会学. 東京, 荅樹書房.

URANO, E., 1990a. Factors affecting the cost of polygynous breeding for female Great Reed Warblers Acrocephalus arundinaceus. Ibis 132: 584-594.

- 1990b. Intra-sexual relationships among polygynously mated female Great Reed Warblers Acrocephalus arundinaceus. Jap. J. Ornithol. 38: 109-118.

VERNER, J., 1964. Evolution of polygamy in the Long-billed Marsh Wren. Evolution 18: 252-261.

—_ 1965. Breeding biology of the Long-billed Marsh Wren. Condor 67: 6-30.

山岸 哲, 1984. 繁殖システム. 森岡弘之・中村登流・樋口広芳 (編), 現代の鳥類学：64-86. 東京, 朝倉書店.

山階芳麿, 1941. 日本の鳥類と其生態. 第二巻. 東京, 岩波書店.

(1991 年 10 月 5 日受理) 